\title{
An Integrated Badnavirus Is Prevalent in Fig Germplasm
}

\author{
Alma G. Laney, Mohamed Hassan, and Ioannis E. Tzanetakis
}

Department of Plant Pathology, Division of Agriculture, University of Arkansas, Fayetteville 72701. First and second authors contributed equally to this work.

Accepted for publication 4 September 2012.

\begin{abstract}
Laney, A. G., Hassan, M. and Tzanetakis, I. E. 2012. An integrated badnavirus is prevalent in fig germplasm. Phytopathology 102:11821189.

Fig mosaic occurs worldwide and is the most common and important viral disease of fig. In the quest to identify the causal agent of the disease, several new viruses have been identified, including a new DNA virus, the subject of this communication. Phylogenetic analysis placed the virus, provisionally named Fig badnavirus-1 (FBV-1), in the genus Badnavirus,

ated and the virus was mechanically transmitted to several herbaceous hosts. FBV-1 was detected in the National Clonal Germplasm Repository fig collection and additional samples from Arkansas, California, Florida, Michigan, Ohio, Oregon, and South Carolina, suggesting its wide distribution in the United States. Further tests revealed the presence of FBV-1 in seedlings and meristem tissue culture plants. Forty-four isolates were used in a study evaluating the population structure of the virus in the United States. Evidence that FBV-1 is integrated in the fig genome is presented and discussed.
\end{abstract} family Caulimoviridae. The experimental host range of FBV-1 was evalu-
Fig (Ficus carica L.; family Moraceae) is a deciduous fruit tree, native of Eurasia. It has been cultivated for thousands of years for its edible fruit and is usually propagated from hardwood cuttings. Fig is susceptible to only a few pathogens and diseases with Armillaria and Rosellinia root rots (caused by Armillaria mellea and Rosellinia necatrix, respectively) and mosaic being of major concern $(26,29)$.

Fig mosaic (FM) was first described in California in 1933 (5) and has since been found worldwide $(9,13)$. The putative causal agent of FM, Fig mosaic virus (FMV), was only recently discovered and characterized $(9,13,44)$. In addition to FMV, several new viruses were found in FM trees including at least five species in the family Closteroviridae $(10-12,15,30,41)$ and one member in each of the genera Trichovirus, Umbravirus, Luteovirus, Carlavirus, Potyvirus, and Alphacryptovirus $(14,16,44)$. A survey of almost 190 trees in California found FMV in the vast majority but not all FM trees (44) and Koch postulates have yet to be completed for FMV/FM. Also, FM symptomology varies greatly between trees of the same or different cultivars ranging from mild mottling to severe mosaic to leaf distortion and ringspots $(1,14$; Fig. 1). The inability to complete Koch postulates, lack of absolute association between FMV and FM, discovery of the myriad of new viruses in FM trees, and extreme symptom variability imply that the disease is more complex than originally thought and symptoms may not only be caused by FMV but also by mixed virus infections as is the case with diseases of several other perennial crops $(27,34,37)$.

In 2008, and in the process of characterizing the FM agent, several new viruses were discovered in an FM tree (41). One of the viruses had sequence similarities to Cacao swollen shoot virus (CSSV) and Citrus yellow mosaic virus (CiYMV), members of

Corresponding author: I. E. Tzanetakis; E-mail address: itzaneta@uark.edu

* The $\boldsymbol{e}$-Xtra logo stands for "electronic extra" and indicates that Figure 1 appears in color online.

http://dx.doi.org/10.1094/PHYTO-12-11-0351

(C) 2012 The American Phytopathological Society the genus Badnavirus. Badnaviruses are double-stranded DNA pararetroviruses that can integrate in the host genome (20) but also actively replicate as episomal, infectious viruses. Badnaviruses have circular genomes of 7 to $8 \mathrm{~kb}$ and are encapsidated in nonenveloped bacilliform virions. They are usually transmitted by mealybugs, although one of them, Rubus yellow net virus, is transmitted by aphids (23). Badnavirus symptoms vary greatly from latent infections, as is the case of Sugarcane bacilliform virus (SCBV) in sugarcane $(3,4)$, to severe, such as the disease caused by CSSV (35) or the Banana streak virus complexes (6, 21,31 ) in cacao and banana, respectively.

The new virus, provisionally named Fig badnavirus-1 (FBV-1), was fully characterized at the molecular level and several experimental hosts were identified. Detection tests were developed and used to determine the presence of the virus in both FM and asymptomatic trees. FBV-1 was found in a high percentage of fig accessions from the National Clonal Germplasm Repository (NCGR) in Davis, California and a population structure study was initiated to determine whether there are distinct virus populations in the United States or whether isolates were imported with one or more accessions from their countries of origin. The possibility that FBV-1 integrates into the fig genome was explored using several approaches.

\section{MATERIALS AND METHODS}

Virus characterization. Nucleic acids were extracted from fig tissue using modified forms of the Yoshikawa and Converse (47) and Tzanetakis and Martin (42) protocols. Nucleic acids were subjected to RNase digestion at $37^{\circ} \mathrm{C}$ overnight for both methods. After digestion, the nucleic acids were bound to silica milk using STE (10 mM Tris-HCl, 1 mM EDTA, pH 8.0)/50\% ethanol (39), eluted in $100 \mu \mathrm{l}$ of TE, reverse transcribed, amplified and cloned as described (42). The obtained sequences were subjected to BLAST (2) to identify viral sequences and compiled into contigs using CAP3 (20). Several virus sequences were acquired including those of an apparently new badnavirus. Sequence gaps between badnavirus sequences were obtained using polymerase chain reaction $(\mathrm{PCR})$ with virus-specific primers or combination 
of rolling circle amplification (RCA) $(7,22)$ and PCR (Table 1). All amplicons were cloned, sequenced, and assembled using CAP3 (20) to obtain the virus genome with an at least $3 \times$ genome coverage (GenBank accession no. JF411989).

Protein conserved domains were identified using the conserved domain database (CDD) (25) and proteins were subjected to BindN (45) to determine DNA-binding domains (at 85\% specificity). Phylogenetic analysis was performed with ClustalW (38) using the neighbor-joining algorithm, Kimura's correction and bootstrap consisting of 1,000 pseudoreplicates. Trees were visualized on TreeView (32).

Detection. Total nucleic acids were purified as described before (40) and used as template for PCR amplification using primers 1094F/1567R (400 nM final concentration; Table 1). PCR was performed using Taq polymerase (GenScript) and a program consisting of initial denaturation at $94^{\circ} \mathrm{C}$ for 2 min followed by $94^{\circ} \mathrm{C}$ for $30 \mathrm{~s}, 55^{\circ} \mathrm{C}$ for $20 \mathrm{~s}$, and $72^{\circ} \mathrm{C}$ for $30 \mathrm{~s}$ repeated for 40 cycles. The protocol terminated with a final extension step at $72^{\circ} \mathrm{C}$ for $10 \mathrm{~min}$. Thirty-five amplicons were sequenced and all were FBV-1, verifying virus-specific detection.

Southern blot hybridization was employed to determine whether the virus is integrated in the fig genome or is actively replicating. Fig genomic DNA was extracted as previously described (8) followed by overnight digestion with T1 RNase (10 $\mu$, Sigma) at $37^{\circ} \mathrm{C}$ and phenol-chloroform extraction. Equal amount of DNA extracts (15 to $20 \mu \mathrm{g}$ each) were digested overnight with SspI and EcoRI at $37^{\circ} \mathrm{C}$. After gel electrophoresis, the DNA was transferred overnight onto Hybond $\mathrm{N}+$ membrane (GE Healthcare) and UV cross-linked. The probe was prepared using a $1094 \mathrm{~F} / 1567 \mathrm{R}$ purified amplicon $(20 \mathrm{ng})$ and labeled using the DIG-High Prime Kit (Roche Applied Science) according to the manufacturer's recommendations. After hybridization, membranes were washed in $0.5 \times \mathrm{SSC}(1 \times \mathrm{SSC}$ is $0.15 \mathrm{M} \mathrm{NaCl}$ plus $0.015 \mathrm{M}$ sodium citrate) $/ 0.1 \%$ sodium dodecyl sulfate (SDS) at $65^{\circ} \mathrm{C}$ and exposed to X-ray film.

For RCA, total nucleic acids were extracted from symptomatic tissue (40) and amplified using the Illustra TempliPhi 100 amplification kit (GE Healthcare) and primer 5900F (800 nM final concentration; Table 1) according to manufacturer's recommendations. Amplified DNA was digested with SspI or MluI, both of which cut the genome at a single site. Product were blotted for Southern blot as described above or purified using an Illustra column (GE Healthcare) for use as template at a 1/100 dilution for PCR amplification as described above. A total of 16 direct PCR FBV-1-positive samples were analyzed using this approach.

For RT-PCR, total nucleic acids from the same 16 samples were digested with $1 \mu \mathrm{l}$ of DNase I in the corresponding buffer
(Fermentas) and 40 units of RiboLock RNase inhibitor for $1 \mathrm{~h}$ at $37^{\circ} \mathrm{C}$. The digested material was adjusted to $50 \%$ ethanol and bound to silica milk to sequester the RNA and remove proteins (40). For the reverse transcription, 100 units of Maxima Reverse Transcriptase (Fermentas), 5× RT buffer, $20 \mu \mathrm{l}$ of RiboLock RNase inhibitor, $5 \mu \mathrm{l}$ of DNase I-digested template, and water to $50 \mu \mathrm{l}$ was incubated at $50^{\circ} \mathrm{C}$ for $1 \mathrm{~h}, 85^{\circ} \mathrm{C}$ for 5 min for enzyme inactivation followed by PCR as described above.

Geographic range and population structure. To determine the FBV-1 distribution, 39 trees from the NCGR in Davis, California, 60 seedlings generated through meristem tip-cultured tissue, and 18 additional samples from Arkansas, California, Florida, Michigan, Ohio, Oregon, and South Carolina were tested using the detection protocol mentioned above (Table 2). The diversity for 44 isolates, 27 from the NCGR, six from Arkansas, including the original isolate, three from Oregon, two meristem plantlets, two seedlings, and one each from Florida, Michigan, Ohio, and South Carolina were investigated by RCA to confirm the episomal form of the studied isolates. A 1,091-nucleotide (nt) region of the virus genome was amplified with primers 580F/ 1650R (Table 1). Sequences were aligned and compared using ClustalW (38) at the nucleotide and amino acid level (GenBank accession nos. JN050858-84, JN112365-69, and JQ282668-78).

Host range. At least six plants from 19 herbaceous host indicator species (Table 3) were inoculated with leaf tissue from the fig tree used in the virus characterization. Tissue was ground in

TABLE 1. Primers used for acquisition of Fig badnavirus-1 (FBV-1) genome and detection

\begin{tabular}{lcl}
\hline Primer type & Primer name & \multicolumn{1}{c}{ Primer sequence } \\
\hline Sequencing & $344 \mathrm{R}$ & ACTGCTAGATTATGGTAAAGGT \\
& $1400 \mathrm{R}$ & TACACAAAGCATCGCTTCCTCGGATCT \\
$1800 \mathrm{~F}$ & AATGTTGGATTTGCTTACAGAATA \\
$2202 \mathrm{~F}$ & ACCCTGGGAGAACCAAGCGG \\
& $2724 \mathrm{R}$ & CTACCATCAGCCCAACA \\
& $3260 \mathrm{R}$ & GTACCACCCCTGATACGACTCCTG \\
& $3900 \mathrm{~F}$ & ATTGTCCTTTGTGTCTCCTAACA \\
& $4955 \mathrm{R}$ & TTGCCCTGATGACTCCTAAATCCA \\
& $5900 \mathrm{~F}$ & CCTATGCTAGTGGGAAGTTTA \\
& $6409 \mathrm{R}$ & CTTCTTCAACCTCCCTGAGT \\
& $6456 \mathrm{~F}$ & TGGAACAATACAGGCAGATT \\
& $1094 \mathrm{~F}$ & ACCAGACGGAGGGAAGAAAT \\
& $1567 \mathrm{R}$ & TCCTTGCCATCGGTTATCTC \\
Detection & $580 \mathrm{~F}$ & AGGCTCTAAGGTTAACTGAAG \\
& $1650 \mathrm{R}$ & ATCATCATCGTGTCAGGTATC \\
\hline
\end{tabular}

${ }^{\text {a }}$ Primer used in the rolling circle amplification reaction to amplify FBV-1specific concatemers. F, forward; R, reverse.
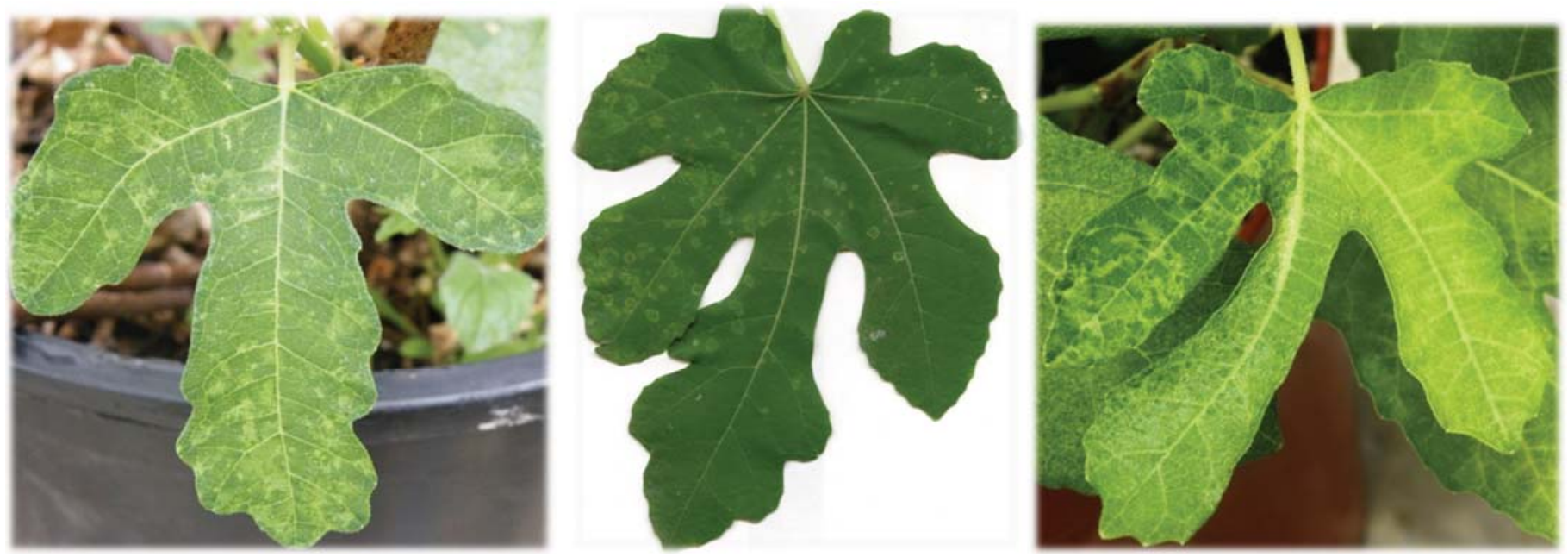

Fig. 1. Variation of fig mosaic disease symptoms. 
cold $0.05 \mathrm{M}$ phosphate buffer $(\mathrm{pH} 7.0)$ at approximately a $1 / 10$ (wt/vol) ratio. The plants were kept in an insect-free greenhouse with 14-h light/10-h dark photoperiod and tested by PCR 1 month postinoculation. All positive PCR amplicons were verified by sequencing.

\section{RESULTS}

Virus acquisition and characterization. The viral genome comprises 7,140 nts and contains a negative strand tRNA ${ }^{\mathrm{MET}}$ primer-binding site (TGGTATCAGAGC 1-12 ), which was chosen as the starting location for the genome (3). A TATA-box was found upstream of the primer site TATAAG $_{6950-6955}$ ) and is part of the promoter region for badnavirus replication (28), though the exact promoter location requires experimental confirmation. The genome encodes four proteins (P1 to P4) of 143, 135, 1837, and 142 amino acids (aa) with molecular masses of 15.3, 16.5, 212.3, and $17.0 \mathrm{kDa}$ respectively (Fig. 2). FBV-1 is closely related to CSSV, CiYMV, and Dioscorea bacilliform AL virus all of which are dicot-infecting badnaviruses (Fig. 3). FBV-1 shares 61 and $64 \%$ nt identities with CSSV and CiYMV over the length of the genome. P1 shares 59 and 55\% nt identities to the CSSV and CiYMV orthologs, respectively. The protein function is yet to be elucidated. P2, a putative DNA binding protein (21), shares over

TABLE 2. Cultivars from Arkansas, California, Florida, Michigan, Ohio, Oregon, and South Carolina and trees grown from seed tested for Fig badnavirus-1 (FBV-1)

\begin{tabular}{|c|c|c|c|c|c|}
\hline Lab sample ${ }^{a}$ & DFIC no. & Cultivar & FBV-1 presence & Symptoms & GenBank accession no. \\
\hline AR1 & N/A & Unknown & + & Fig mosaic & JF411989 \\
\hline AR2 & N/A & Unknown & + & None & JN112365 \\
\hline AR3 & N/A & Brown Turkey & + & None & JN112366 \\
\hline AR4 & N/A & Black Mission & + & None & JN112367 \\
\hline AR5 & N/A & Kadota & + & None & JN112368 \\
\hline AR6 & N/A & Kadota & + & None & JN112369 \\
\hline AR7 & N/A & Unknown & - & None & N/A \\
\hline CA1 & 1 & Vernino & - & Fig mosaic & N/A \\
\hline $\mathrm{CA} 2$ & 6 & UCR 347-1 & - & Fig mosaic & N/A \\
\hline CA3 & 9 & Flanders & + & Fig mosaic & N/A \\
\hline $\mathrm{CA} 4$ & 15 & DiRedo & + & Fig mosaic & N/A \\
\hline CA5 & 17 & Brown Turkey & + & Fig mosaic & N/A \\
\hline CA6 & 36 & Zidi & + & Fig mosaic & N/A \\
\hline $\mathrm{CA} 7$ & 53 & St Jean & + & Fig mosaic & N/A \\
\hline CA8 & 57 & Calimyrna & + & Fig mosaic & N/A \\
\hline CA9 & 63 & Violette De & + & Fig mosaic & N/A \\
\hline CA10 & 63 & Violette De & + & Fig mosaic & JN050858 \\
\hline CA11 & 65 & UCR 143-28 & + & Fig mosaic & JN050859 \\
\hline CA12 & 67 & Monstrueuse & + & Fig mosaic & JN050860 \\
\hline CA13 & 69 & Barnissotte & + & Fig mosaic & JN050861 \\
\hline CA14 & 77 & Calvert & + & Fig mosaic & JN050862 \\
\hline CA15 & 80 & Celeste & + & Fig mosaic & JN050863 \\
\hline CA16 & 84 & Dauphine & + & Fig mosaic & JN050864 \\
\hline CA17 & 87 & Snowden & + & Fig mosaic & JN050865 \\
\hline CA18 & 88 & Pied De Boef & + & Fig mosaic & JN050866 \\
\hline CA19 & 90 & Ischis Black & + & Fig mosaic & JN050867 \\
\hline CA20 & 101 & UCR 326-1 & + & Fig mosaic & N/A \\
\hline CA21 & 102 & UCR 284-11 & + & Fig mosaic & JN050868 \\
\hline CA22 & 102B & UCR 284-11 & + & Fig mosaic & JN050869 \\
\hline CA23 & 105 & UCR K-7-11 & + & Fig mosaic & JN050870 \\
\hline CA24 & 105 & UCR K-7-11 & + & Fig mosaic & N/A \\
\hline $\mathrm{CA} 25$ & 105 & UCR K-7-11 & + & Fig mosaic & JN050871 \\
\hline CA26 & 110 & hybrid & + & Fig mosaic & JN050872 \\
\hline CA27 & 111 & Santa Cruz White & + & Fig mosaic & JN050873 \\
\hline CA28 & 112 & Rattlesnake & + & Fig mosaic & JN050874 \\
\hline CA29 & 112 & Rattlesnake & + & Fig mosaic & N/A \\
\hline CA30 & 113 & Capitola Long & + & Fig mosaic & JN050875 \\
\hline CA31 & 124 & Capri P & + & Fig mosaic & JN050876 \\
\hline CA32 & 147 & Black Fig 1 & + & Fig mosaic & JN050877 \\
\hline CA33 & 147 & Black Fig 1 & + & Fig mosaic & JN050878 \\
\hline CA34 & 153 & Castle Kennedy & + & Fig mosaic & JN050879 \\
\hline CA35 & 155 & Californina Grown & + & Fig mosaic & JN050880 \\
\hline CA36 & 158 & Pseudocarica & + & Fig mosaic & JN050881 \\
\hline CA37 & 158 & Pseudocarica & + & Fig mosaic & JN050882 \\
\hline CA38 & 185 & KAC 11-7W & + & Fig mosaic & JN050883 \\
\hline CA39 & 187 & KAC $16-32 W$ & + & Fig mosaic & JN050884 \\
\hline CA40 & N/A & White Genoa & + & Fig mosaic & N/A \\
\hline CA41 & N/A & Sierra & + & None & JQ282675 \\
\hline CA42 & N/A & Sequoia & + & None & JQ282676 \\
\hline FL1 & N/A & Ischia & + & None & JQ282674 \\
\hline FS1 & N/A & Unknown & + & None & JQ282677 \\
\hline $\mathrm{FS} 2$ & N/A & Unknown & + & None & JQ282678 \\
\hline MI1 & N/A & Green Ischia & + & None & JQ282673 \\
\hline $\mathrm{OH} 1$ & N/A & Hardy Chicago & + & None & JQ282668 \\
\hline OR 1 & N/A & Brown Turkey & + & Fig mosaic & JQ282669 \\
\hline OR2 & N/A & Desert King & + & None & JQ282670 \\
\hline OR3 & N/A & Black Mission & + & Fig mosaic & JQ282671 \\
\hline SC1 & N/A & Texas Everbearing & + & None & JQ282672 \\
\hline
\end{tabular}

a Abbreviations: AR, Arkansas; CA, California; FL, Florida; FS, fig seedling grown from seed; MI, Michigan; OH, Ohio; OR, Oregon; and SC, South Carolina.

b Complete genome sequence. 
$40 \%$ nt identities to both CSSV and CiYMV orthologs. As in the case of CSSV (21), the terminal residues of FBV-1 p2 are predicted to strongly bind DNA (45). The key Badnavirus motifs were found in the polyprotein; however, no protease cleavage sites could be identified in silico similar to other badnaviruses. The signature motifs (3) include movement protein ( $\left.\operatorname{Arg}_{135}-\mathrm{PrO}_{196}\right)$, the coat protein zinc-finger domain $\left(\mathrm{Lys}_{813}-\mathrm{Pro}_{829}\right)$, pepsin-like aspartate protease $\left(\mathrm{Val}_{1085}-\mathrm{Gly}_{1163}\right)$, reverse transcriptase $\left(\mathrm{Leu}_{1279^{-}}\right.$ $\left.\mathrm{Gly}_{1481}\right)$, and RNase $\mathrm{H}\left(\mathrm{Thr}_{1583}-\mathrm{Leu}_{1704}\right)$. The protein shares 54 and $57 \%$ nt identities to CSSV and CiYMV orthologs, respectively. The reverse transcriptase and RNase $\mathrm{H}$ regions share less than $74 \%$ identities with any sequenced badnavirus. FBV-1 has four open reading frames (ORFs), similar to CSSV but unlike most other badnaviruses. ORF4 codes for a putative protein of un-

TABLE 3. Herbaceous hosts mechanically inoculated with accession AR1, source to the type isolate of Fig badnavirus-1 (FBV-1)

\begin{tabular}{|c|c|c|}
\hline Indicator species & Symptoms & $\begin{array}{c}\text { FBV-1 PCR- } \\
\text { positives }^{\mathrm{a}}\end{array}$ \\
\hline \multicolumn{3}{|l|}{ Cucurbita pepo cv. Connecticut Field } \\
\hline Pumpkin & Mosaic & $8 / 12$ \\
\hline Glycine $\max \mathrm{cv}$. Lee & Mild mosaic & $2 / 36$ \\
\hline Pisum sativum $\mathrm{cv}$. Wando & None & $11 / 20$ \\
\hline Nicotiana occidentalis & None & $6 / 8$ \\
\hline Nicotiana tabacum & None & $4 / 8$ \\
\hline Nicotiana sylvestris & None & $4 / 8$ \\
\hline Nicotiana rustica & None & $4 / 8$ \\
\hline Nicotiana benthamiana & None & $0 / 14$ \\
\hline Cucumis sativus cv. National Pickling & None & $0 / 20$ \\
\hline Cucumis melo cv. Edisto 47 cantaloupe & None & $0 / 6$ \\
\hline Vigna unguiculata $\mathrm{cv}$. Monarch & None & $0 / 18$ \\
\hline Phaseolus vulgaris var. Black Valentine & None & $0 / 8$ \\
\hline Gomphrena globosa & None & $0 / 12$ \\
\hline Spinacia oleracea cv. Bloomsdale & None & $0 / 16$ \\
\hline Chenopodium amaranticolor & None & $0 / 18$ \\
\hline Chenopodium quinoa & None & $0 / 22$ \\
\hline Beta vulgaris cv. Ruby Queen & None & $0 / 12$ \\
\hline Solanum lycopersicum cv. Beefsteak & None & $0 / 12$ \\
\hline Brassica rapa subsp. pekinensis & None & $0 / 8$ \\
\hline
\end{tabular}

${ }^{a}$ All positive amplicons were verified by sequencing the product. known function. No significant similarity, except for the putative CSSV P4 ortholog (28\% aa identities), was identified and no function was elucidated using CDD, Psi-, and Phi-Blast. According to the guidelines of the Ninth ICTV Report (24), FBV-1 is a new member of the genus Badnavirus as the RT/RNaseH region shares less than $80 \%$ identity to other members of the genus.

Integration and replication. The taxonomic placement of FBV-1 as a new badnavirus led to the notion that the virus may, in addition to actively replicate, also integrate into the fig genome. To explore this hypothesis, genomic fig DNA was used in Southern blot hybridization. Digestion with $S s p I$, an endonuclease with a single recognition site in the FBV-1 genome, produced signal at the approximate genomic size of $7 \mathrm{~kb}$; additional signals were detected at 3, 4.5, and $6 \mathrm{~kb}$ (Fig. 4). EcoRI has three recognition sites in the virus genome, with the probe hybridizing to a $5.4-\mathrm{kb}$ fragment. In addition to the 5.4-kb signal, additional bands were detected at $3.5,4,4.5,7$, and $7.5 \mathrm{~kb}$. The hybridization signal from undigested DNA occurred much above $10 \mathrm{~kb}$ (Fig. 4). The additional bands detected in the digested material, in addition to the signal at high molecular weight of the undigested samples, provide evidence that FBV-1 integrates in the fig genome. RCA and RT-PCR were also employed to differentiate between integrated and episomal virus in different fig accessions as described previously (22). Genome amplification using RCA followed by Southern blot verified that FBV-1 is episomal in the material used for the virus characterization (Fig. 4). However, we considered that not all fig samples might contain episomal forms of the virus. For this reason, 16 direct PCR-positive samples were also assayed by RCA and RT-PCR. Total nucleic acids were subjected to RCA followed by digestion using $S s p I$. Fragments of nearly $7 \mathrm{~kb}$ in size were only observed in 7 out of 16 fig samples, whereas RT-PCR assays were in agreement with the RCA results (Fig. 5). These results provide evidence that FBV-1 exists in both episomal and/or integrated forms.

Geographic range and diversity. A diverse array of different fig accessions was tested using direct PCR for FBV-1 including: 39 FM accessions from the NCGR in Davis, California; 60 plantlets generated by meristem tissue culture; six asymptomatic trees from Arkansas; three fig seedlings, three samples from Oregon,

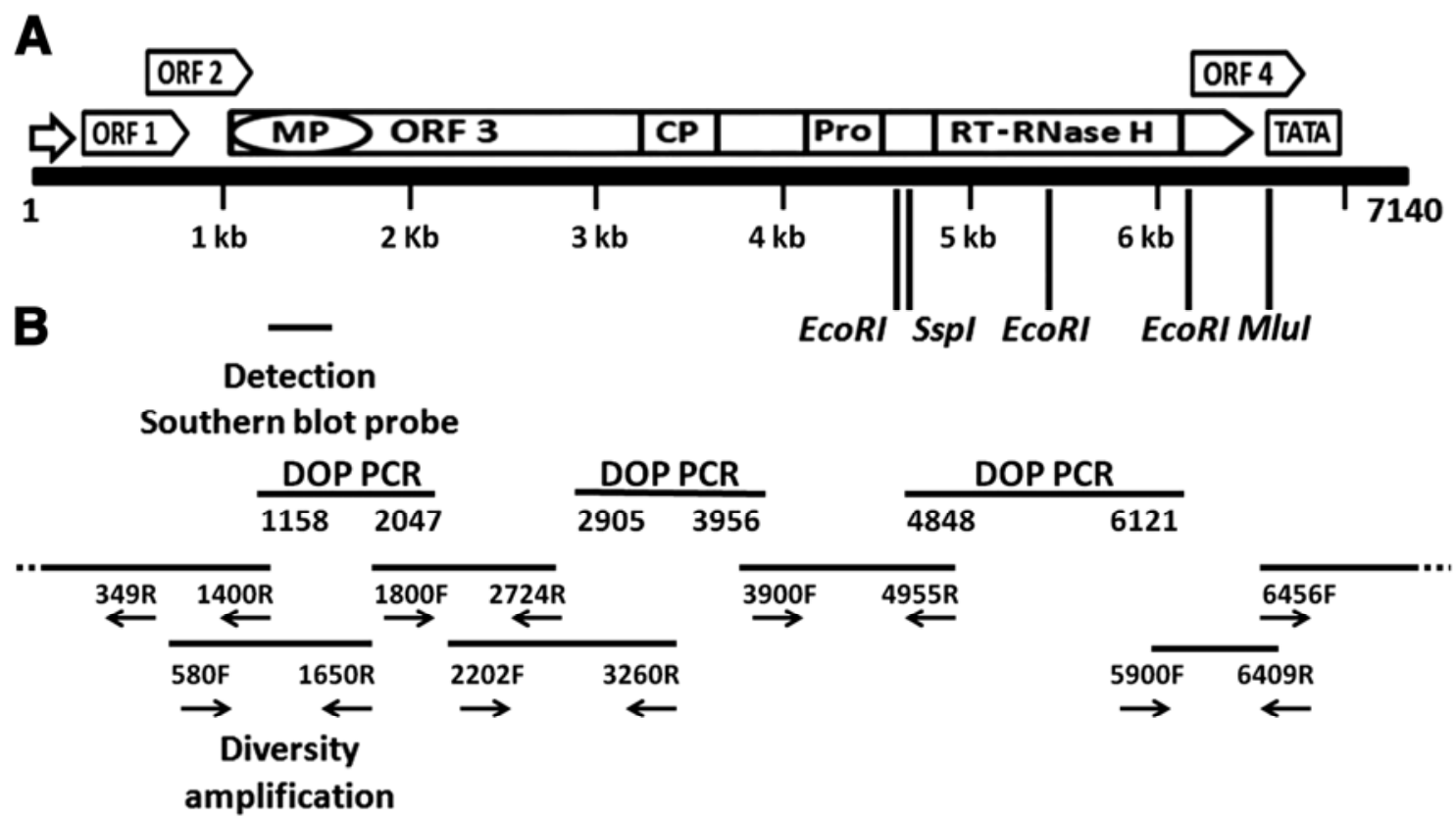

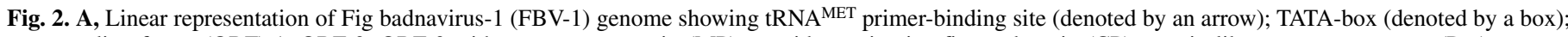

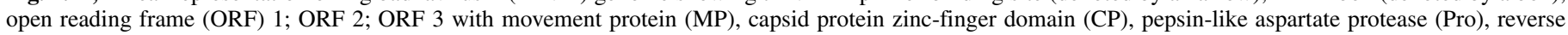

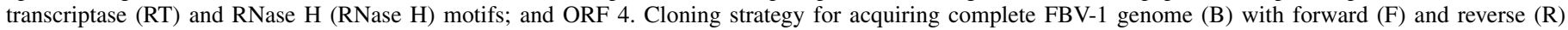

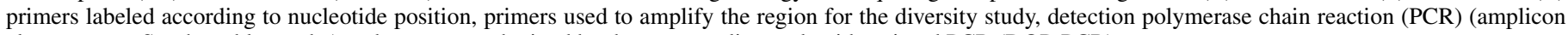
also serves as Southern blot probe) and sequences obtained by degenerate oligonucleotide-primed PCR (DOP-PCR). 
and one each from nurseries in California, Florida, Michigan, Ohio, and South Carolina. FBV-1 was found in both FM-symptomatic and asymptomatic trees (Fig. 6). A total of 114 samples out of the 117 tested were found infected with FBV-1, including all the meristem tip culture plants and three seedlings; only two samples from the NCGR and one from Arkansas tested negative for FBV-1. Those samples were tested three times starting from tissue extraction and using all the detection techniques described above other than Southern blot hybridization. In order to verify the extraction of good quality material, an internal control was used as described (43).

The virus population, as studied by sequencing two genes of 44 isolates, proved to be homogeneous with nucleotide identities ranging from 99 to $100 \%$. ORF2 amino acid identities ranged from 98 to $100 \%$. Similarly, sequence analysis of the $\mathrm{N}$ terminus of ORF3 (196 aa) revealed amino acid identities ranging from 97 to $100 \%$.

Host range. FBV-1 was detected in systemic leaves of Nicotiana occidentalis, N. tabacum, N. sylvestris, N. rustica, Pisum sativum, Cucurbita pepo, and Glycine max with the latter two hosts developing mosaic symptoms. However, inoculations were performed and tissue tested before the identification of the several new viruses discovered in fig and thus symptoms cannot be attributed solely to FBV-1 as the herbaceous hosts were not tested for some of the 10 or more new viruses that may have been present in the source tree.

\section{DISCUSSION}

Badnaviruses are some of the most important viruses for world agriculture, not only due to the severe diseases they cause (6, $21,23,35)$ but also because of their ability to integrate in the host genome $(6,17,31)$. Genome integration can also be a research calamity as presence of an integrated virus does not always trans- late to an active virus. One of the most important questions after the discovery of badnavirus sequences, known to bear similarities to retrotransposons, is whether the virus-like findings are integrated in the host genome and/or are found in episomal form and therefore actively replicating. Using RCA, Southern blotting, RTPCR, and mechanical transmission to herbaceous hosts, we determined that FBV-1 can be episomal and not an inactive, genetic fossil integrated in the host genome.

After confirmation of active virus replication, the obvious question was whether the pathogen causes disease. FBV-1 was detected in several asymptomatic samples, including some from Arkansas that were monitored for more than 2 years, evidence that FBV-1 is asymptomatic in single infections, at least in some cultivars. However, given the great number of cultivars available, this may not be true for others. There is also the distinct possibility that FBV-1 infection alters the internal physiology of the host as has been recently shown with Fig leaf mottle-associated virus-1 (15). Badnaviruses are also known to play an important role in disease complexes, as is the case of Rubus yellow net virus, an integral part of the Raspberry mosaic disease (23), and there are numerous reports of mixed infections causing severe symptoms in clonally propagated crops $(23,37,39,40,46)$. The implication of the potential mayhem caused directly or indirectly by FBV-1 warrants further study to understand the virus epidemiology and population structure and set the basis for virus control in the nursery propagation stage.

There are several fig nurseries in the United States from California to Florida, propagating a wide assortment of fig germplasm. In the case of a new, apparently symptomless virus such as FBV-1, this practice can lead to dissemination of highly variable isolates which may have different effects on the onset of disease in the presence of other viruses, as noted above, or to possible recombination events and the emergence of more virulent isolates $(18,19,36)$. For this reason, and given the high number of infected

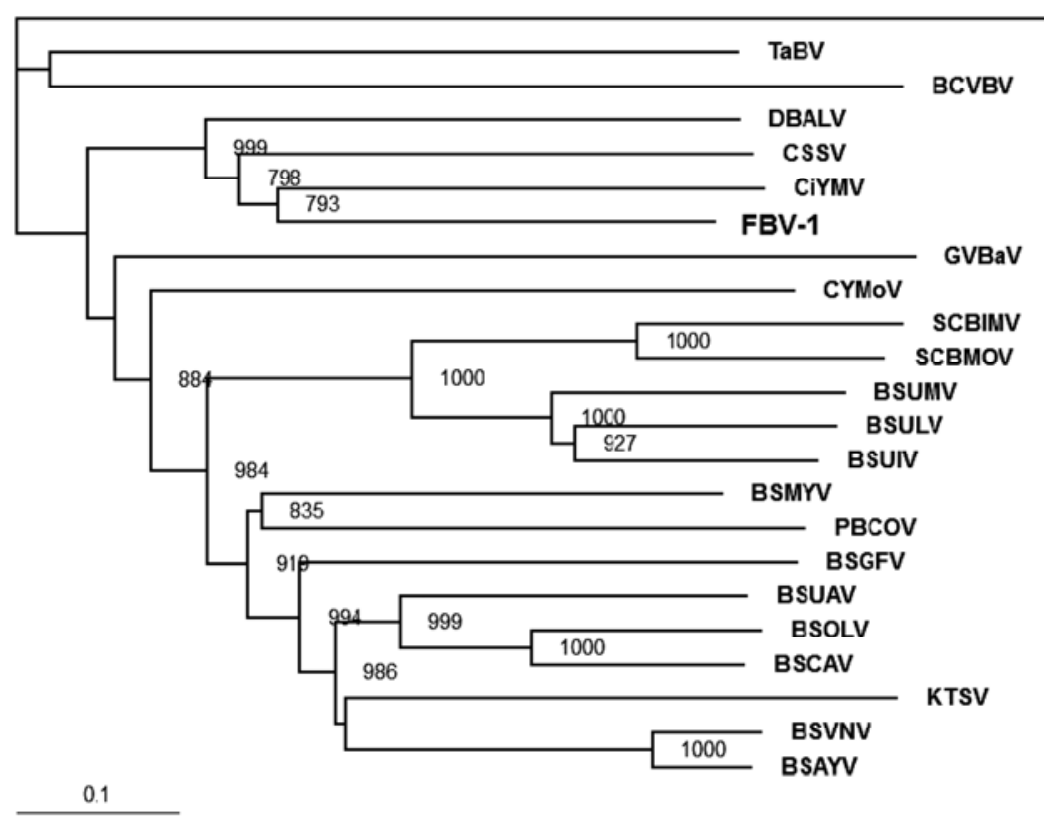

Fig. 3. Phylogram using the genome nucleotide sequence for members of the genus Badnavirus. Virus sequences used: Fig badnavirus-1 (FBV-1; JF411989); Taro bacilliform virus (TaBV; NC_004450); Bougainvillea chlorotic vein-banding virus (BCVBV; NC_011592); Dioscorea bacilliform AL virus (DBALV; NC_009010); Cacao swollen shoot virus (CSSV; NC_001574); Citrus yellow mosaic virus (CiYMV; NC_003382); Commelina yellow mottle virus (CoYMV; NC_001343); Banana streak GF virus (BSGFV; NC_007002); Sugarcane bacilliform IM virus (SCBIMV; NC_003031); Sugarcane bacilliform MO virus (SCBMOV; NC_008017); Banana streak MY virus (BSMYV; NC_006955); Banana streak AY virus (BSAYV; DQ092436); Banana streak VN virus (BSVNV; NC_007003); Banana streak OL virus (BSOLV; NC_003381); Banana streak CA virus (BSCAV; NC_015506); Banana streak UM virus (BSUMV; NC_015505); Banana streak UL virus (BSULV; NC_015504); Banana streak UI virus (BSUIV; NC_015503); Banana streak UA virus (BSUAV; NC_015502); Gooseberry vein banding associated virus isolate BC (GVBaV; HQ852250); Pineapple bacilliform CO virus (PBCOV; NC_014648); and Kalanchoe top-spotting virus (KTSV; NC_004540). Cauliflower mosaic virus (CaMV; NC_001497) was used as an outgroup. Bootstrap values less that $70 \%$ are not shown as they are considered unreliable. Bar represents 0.1 changes per site. 
trees, we studied the population diversity of the virus in trees that are separated by thousands of kilometers. The results show that virus diversity is minimal. It is noticeable that isolates from the Near and Middle East are very similar to the U.S. isolates (Barutcu, personal communication). This can be indicative of FBV-1 being under purification selection or one or few isolates that were imported to the United States still circulate in the germplasm without much change.

As FBV-1 was found in a large number of trees of different origins, it is also possible that the virus is being actively transmitted in the United States by a yet undetermined vector, although mechanical transmission through pruning cannot be excluded given that FBV-1 appears to be easily transmissible by mechanical means. However, no commercially available figs or meristem tip culture plants and fig seedlings were found free of FBV-1. Two FBV-1-free accessions from NCGR are infected with at least FMV, and an asymptomatic accession from Arkansas was infected with at least two other viruses (unpublished data) making any trials for FBV-1 mechanical transmission unreliable.

Another more plausible explanation for the widespread nature of FBV-1 is its ability to integrate into the fig genome, given that 113 out of 116 figs tested were FBV-1-positive when using direct PCR. However, the picture is not as clear as a $98 \%$ detection rate. Southern blotting verified virus integration but RCA and RT-PCR assays detected the episomal virus only in a subset of the samples tested, making virus epidemiology rather complex.

The high incidence of FBV-1 integration makes its elimination nearly impossible. Even if the episomal form is eliminated by thermo- and chemotherapy $(33,46)$, there is always the possibility of virus reactivation and disease as found in other crops (31). For this reason, it is important to be aware of virus presence and eliminate infected material from the propagation pipeline. As

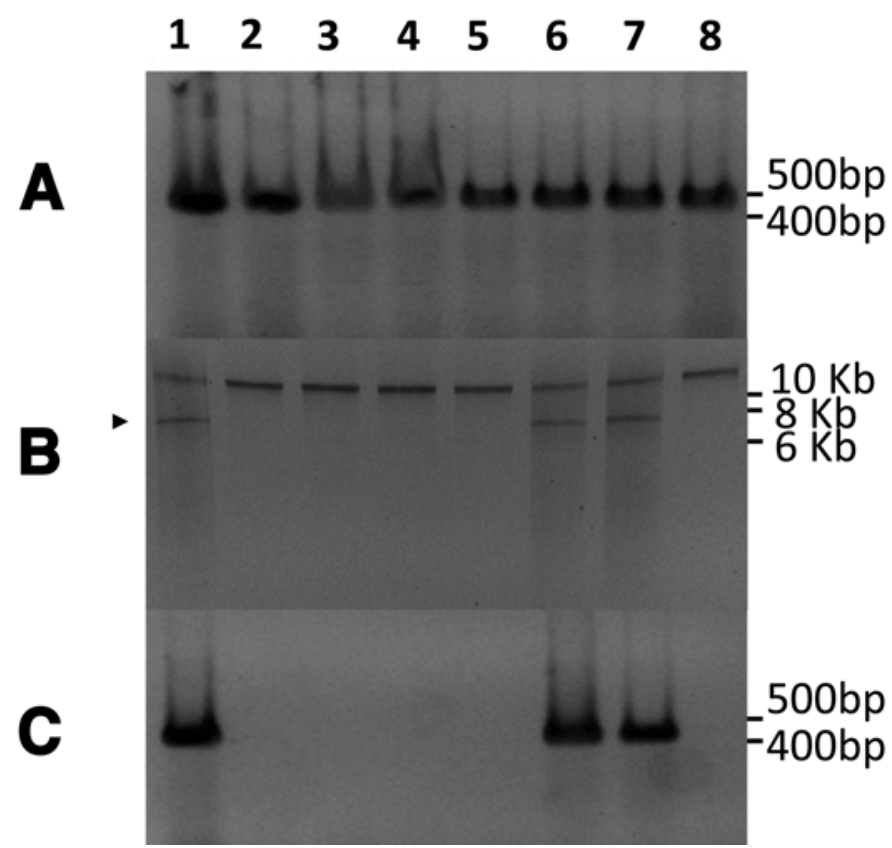

Fig. 5. Results of 8 of the 16 samples used in amplification of fig samples using polymerase chain reaction (PCR), reverse-transcription (RT)-PCR, and rolling circle amplification (RCA) for discrimination between episomal and integrated forms of Fig badnavirus-1 (FBV-1). A, All samples were positive for FMV-1 when total nucleic acids were assayed using primer set 1094F/1567R. By contrast only three of the eight samples (lanes 1, 6, and 7) were positive when subjected to RCA (B; SspI-digested product indicated by arrowhead) or C, RT-PCR.
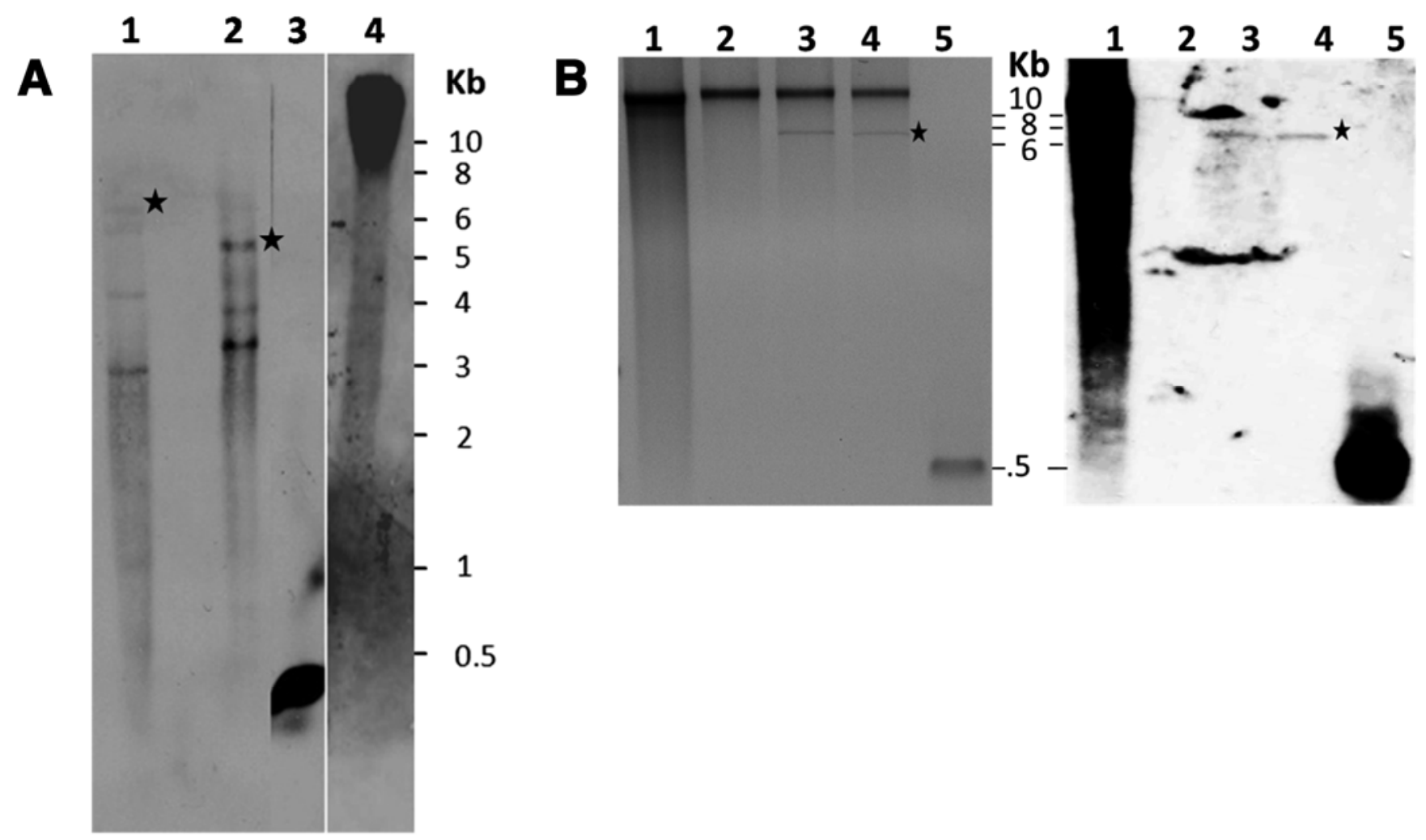

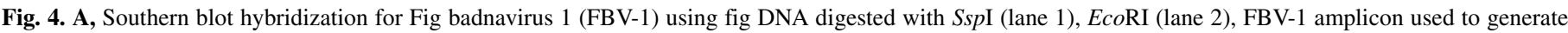

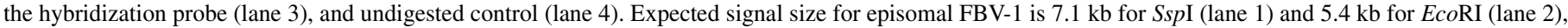

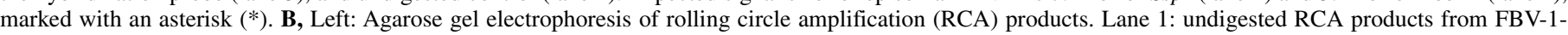

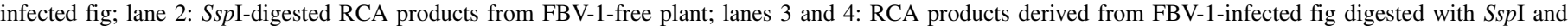

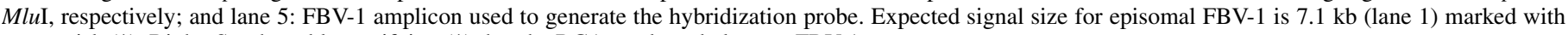
an asterisk (*). Right: Southern blot verifying (*) that the RCA products belong to FBV-1. 


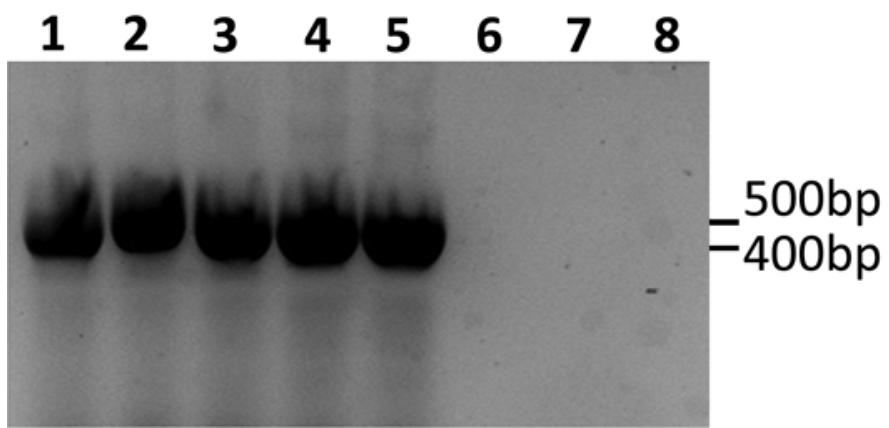

Fig. 6. Detection of Fig badnavirus-1 (FBV-1) in fig. Lane 1, isolate AR1 (fig mosaic-type isolate); lane 2, isolate AR2 (asymptomatic); lane 3, isolate AR3 (asymptomatic); lane 4, isolate CA15 (fig mosaic); lane 5, isolate CA30 (fig mosaic); lane 6, FBV-1-negative Arkansas fig AR7 (asymptomatic); lane 7, FBV-1-negative California fig CA1 (fig mosaic); and lane 8, negative control using water in place of a template.

such, we developed sensitive detection tests for FBV-1 that target the integrated and/or the episomal form of the virus. To minimize the possibility of false negatives because of sequence variations, the detection primers were developed to be $100 \%$ identical to all 44 isolates sequenced.

FBV-1 is not the only badnavirus found in fig as there are unpublished reports of additional badnaviruses from the United States and the Mediterranean (unpublished data; T. Elbeaino, personal communication). Given the association of badnaviruses with severe diseases and their significant role in virus complexes, it is possible that they present a new, unrecognized problem for the fig industry, not only in the United States but also around the world.

\section{ACKNOWLEDGMENTS}

We thank Dr. Barutcu and T. Elbeaino for kindly sharing their fig badnavirus sequences and B. Lockhart for intriguing conversations on FBV-1. Funding for this project was provided from start-up funds given to I. E. Tzanetakis by the Division of Agriculture, University of Arkansas.

\section{LITERATURE CITED}

1. Al-Mughrabi, K. I., and Anfoka, G. H. 2000. Distribution of fig mosaic in Jordan. Phytopathol. Mediterr. 39:263-270.

2. Altschul, S., Madden, T., Schäffer, A., Zhang, J., Zhang, Z., Miller, W., and Lipman, D. 1997. Gapped BLAST and PSI-BLAST: A new generation of protein database search programs. Nucleic Acids Res. 25:3389-3402.

3. Bouhida, M., Lockhart, B., and Olszewski, N. 1993. An analysis of the complete sequence of Sugarcane bacilliform virus genome infectious to banana and rice. J. Gen. Virol. 74:15-22.

4. Braithwaite, K., Egeskov, N., and Smith, G. 1995. Detection of Sugarcane bacilliform virus using the polymerase chain reaction. Plant Dis. 79:792796.

5. Condit, I., and Horne, W. 1933. A mosaic of the fig in California. Phytopathology 23:887-896.

6. Daniels, J. W., Geering, A. D. W., Bryde, N. J., and Thomas, J. E. 2001. The effect of Banana streak virus on the growth and yield of dessert bananas in tropical Australia. Ann. Appl. Biol. 139:51-60.

7. Dean, F., Nelson, J., Giesler, T., and Lasken, R. 2001. Rapid amplification of plasmid and phage DNA using Phi29 DNA polymerase and multiplyprimed rolling circle amplification. Genome Res. 11:1095-1099.

8. Doyle, J. J., and Doyle, J. L. 1990. Isolation of plant DNA from fresh tissue. Focus 12:13-15.

9. Elbeaino, T., Digiaro, M., Alabdullah, A., De Stradis, A., Minafra, A., Mielke, N., Castellano, M. A., and Martelli, G. P. 2009. A multipartite single-stranded negative-sense RNA virus is the putative agent of fig mosaic disease. J. Gen. Virol. 90:1281-1288.

10. Elbeaino, T., Digiaro, M., De Stradis, A., and Martelli, G. P. 2006. Partial characterization of a closterovirus associated with a chlorotic mottling of fig. J. Plant Pathol. 88:187-192.

11. Elbeaino, T., Digiaro, M., De Stradis, A., and Martelli, G. P. 2007. Identification of a second member of the family Closteroviridae in mosaic-diseased figs. J. Plant Pathol. 89:119-124.
12. Elbeanio, T., Digiaro, M., Heinoun, K., De Stradis, A., and Martelli, G. P. 2010. Fig mild mottle-associated virus, a novel closterovirus infecting fig. J. Plant Pathol. 92:165-172.

13. Elbeaino, T., Digiaro, M., and Martelli, G. P. 2009. Complete nucleotide sequence of four RNA segments of fig mosaic virus. Arch. Virol. 154:1719-1727.

14. Elbeaino, T., Kubaa, R., Digiaro, M., Minafra, A., and Martelli, G. P. 2011. The complete nucleotide sequence and genome organization of Fig cryptic virus, a novel bipartide dsRNA virus infecting fig, widely distributed in the Mediterranean Basin. Virus Genes 42:415-421.

15. Fayes, K. A., and Mahmoud, S. Y. 2011. Detection and partial characterization of a putative closterovirus affecting Ficus carica: Molecular, ultrastructural and physiological aspects of infected leaves. Acta Physiol. Plant 33:2187-2198.

16. Gattoni, G., Minafra, A., De Stradis, A., Boscia, D., Elbeaino, T., Diagrio, M., and Martelli, G. P. 2009. Some properties of Fig latent virus-1, a new member of the family Flexiveridae. J. Plant Pathol. 91:555-564.

17. Geering, A. D. W., Olszewski, N. E., Dahal, G., Thomas, J. E., and Lockhart, B. E. L. 2001. Analysis of the distribution and structure of integrated Banana streak virus DNA in a range of Musa cultivars. Mol. Plant Pathol. 2:207-213.

18. Glais, L., Tribodet, M., and Kerlan, C. 2002. Genomic variability in Potato potyvirus $Y$ (PVY): Evidence that $\mathrm{PVY}^{\mathrm{N}} \mathrm{W}$ and $\mathrm{PVY}^{\mathrm{NTN}}$ variants are single to multiple recombinants between $\mathrm{PVY}^{\mathrm{O}}$ and $\mathrm{PVY}^{\mathrm{N}}$ isolates. Arch. Virol. 147:363-378

19. Glasa, M., Palkovics, L., Kominek, P., Labonne, G., Pittnerova, S., Kudela, O., Candresse, T., and Subr, Z. 2004. Geographically and temporally distant natural recombinant isolates of Plum pox virus (PPV) are genetically very similar and form a unique PPV subgroup. J. Gen. Virol. 85:2671-2681

20. Huang, X., and Madan, A. 1999. CAP3: A DNA sequence assembly program. Genome Res. 9:868-877.

21. Jacquot, E., Hagen, L., Jacquemond, M., and Yot, P. 1996. The open reading frame 2 product of Cacao swollen shoot badnavirus is a nucleic acid-binding protein. Virology 225:191-195.

22. James, A., Geijskes, R., Dale, J., and Harding, R. 2011. Development of a novel rolling-circle amplification technique to detect Banana streak virus that also discriminates between integrated and episomal virus sequences. Plant Dis. 95:57-62.

23. Jones, A. T., McGavin, W. J., Geering, A. D. W., and Lockheart, B. E. L. 2002. Identification of Rubus yellow net virus as a distinct badnavirus and its detection by PCR in Rubus species and in aphids. Ann. Appl. Biol. 141:1-10.

24. King, A. M. Q., Adams, M. J., Carstens, E. B., and Lefkowitz, E. J. 2011. Virus Taxonomy: Ninth Report of the International Committee on Taxonomy of Viruses. Academic Press, New York.

25. Marchler-Bauer, A., Anderson, J., Chitsaz, F., Derbyshire, M., DeWeeseScott, C., Fong, J., Geer, L., Geer, R., Gonzales, N., Gwadz, M., He, S., Hurwitz, D., Jackson, J., Ke, Z., Lanczycki, C., Liebert, C., Liu, C., Lu, F., Lu, S., Marchler, G., Mullokandov, M., Song, J., Tasneem, A., Thanki, N., Yamashita, R., Zhang, D., Zhang, N., and Bryant, S. 2009. CDD: Specific functional annotation with the conserved domain database. Nucleic Acids Res. 37:D205-10.

26. Mars, M. 2003. Fig (Ficus carica L.): Genetic resources and breeding. Acta Hortic. 605:19-27.

27. Martin, R. R., MacFarlane, S., Sabanadzovic, S., Quito-Avila, D., Poudel, B., and Tzanetakis, I. E. 2012. Viruses and virus diseases of Rubus. Plant Dis. http://dx.doi.org/10.1094/PDIS-04-12-0362-FE

28. Medberry, S. L., Lockhart, B. E. L., and Olszewski, N. E. 1992. The Commelina yellow mottle virus promoter is a strong promoter in vascular and reproductive tissues. Plant Cell 4:185-192.

29. Michailides, T. J. 2003. Diseases of fig. Pages 253-273 in: Diseases of Tropical Fruit Crops. R. C. Ploetz, ed. CAB International, FL.

30. Nahdi S., Elbeaino T., Digiaro M., and Martelli G. 2006. First record of Fig leaf mottle-associated virus-1 in Tunisia. J. Plant Pathol. 88:S70.

31. Ndowora, T., Dahal, G., LaFleur, D., Harper, G., Hull, R., Olszewski, N. E., and Lockhart, B. E. L. 1999. Evidence that badnavirus infection in Musa can originate from integrated pararetroviral sequences. Virology 255:214-220.

32. Page, R. 1996. TREEVIEW: An application to display phylogenetic trees on personal computers. Comput. Appl. Biosci. 12:357-358.

33. Panattoni, A., D'Anna, F., Cristani, C., and Triolo, E. 2007. Grapevine vitivirus A eradication in Vitis vinifera explants by antiviral drugs and thermotherapy. J. Virol. Methods 146:129-135.

34. Pita, J. S., Fondong, V. N., Sangare, A., Otim-Nape, G. W., Ogwal, S., and Fauquet, C. M. 2001. Recombination, pseudorecombination and synergism of geminiviruses are determinant keys to the epidemic of severe cassava mosaic disease in Uganda. J. Gen. Virol. 82:655-665.

35. Quainoo, A. K., Wetten, A. C., and Allainguillaume, J. 2008. Transmission of cocoa swollen shoot virus by seeds. J. Virol. Methods 150:45-49. 
36. Rubio, L., Ayllon, M. A., Kong, P., Fernandez, A., Polek, M. L., Guerri, J., Moreno, P., and Falk, B. W. 2001. Genetic variation of Citrus Tristeza Virus isolates from California and Spain: Evidence for mixed infections and recombination. J. Virol. 75:8054-8062.

37. Susaimuthu, J., Tzanetakis, I. E., Geregrich, R. C., and Martin, R. R. 2008. A member of new genus in the family Potyviridae infects Rubus. Virus Res. 131:145-151.

38. Thompson, J. D., Higgins, D. G., and Gibson, T. J. 1994. CLUSTALW, improving the sensitivity of progressive multiple sequence alignment through sequence weighting, position-specific gap penalties and weight matrix choice. Nucleic Acids Res. 22:4673-4680.

39. Tzanetakis, I. E., Halgren, A. B., Keller, K. E., Hokanson, S. C., Maas, J. L., McCarthy, P. L., and Martin, R. R. 2004. Identification and detection of a virus associated with strawberry pallidosis disease. Plant Dis. 88:383390.

40. Tzanetakis, I. E., Halgren, A., Mosier, N., and Martin, R. R. 2007. Identification and characterization of Raspberry mottle virus, a novel member of the Closteroviridae. Virus Res. 127:26-33.

41. Tzanetakis, I. E., Laney, A. G., Keller, K. E., and Martin, R. R. 2010. New viruses found in fig exhibiting mosaic symptoms. Julius-Kühn-Archiv. 427:79-82.

42. Tzanetakis, I. E., and Martin, R. R. 2008. A new method for extraction of double stranded RNA from plants. J. Virol. Methods 149:167-170.

43. Tzanetakis, I. E., Postman, J. D., and Martin, R. R. 2007. Identification, detection and transmission of a new Vitivirus from Mentha. Arch. Virol. 152:2027-2033.

44. Walia, J. J., Salem, N. M., and Falk, B. W. 2009. Partial sequence and survey analysis identify a multipartite, negative-sense RNA virus associated with fig mosaic. Plant Dis. 93:4-10.

45. Wang, L., and Brown, S. 2006. BindN: A web-based tool for efficient prediction of DNA and RNA binding sites in amino acid sequences. Nucleic Acids Res. 34:W243-W248.

46. Wang, Q. C., and Valkonen, J. P. T. 2008. Elimination of two viruses which interact synergistically from sweetpotato by shoot tip culture and cryotherapy. J. Virol. Methods 154:135-145.

47. Yoshikawa, N., and Converse, R. H. 1990. Strawberry pallidosis disease: Distinctive dsRNA species associated with latent infections in indicators and in diseased strawberry cultivars. Phytopathology 80:543-554. 